\title{
Intraventricular haemorrhage and obstructive hydrocephalus in a term neonate: an uncommon presentation of haemophilia $B$
}

\author{
Deepanjan Bhattacharya, Indar Kumar Sharawat, Lokesh Saini
}

Pediatric Neurology Unit, Department of Pediatrics, Postgraduate Institute of Medical Education and Research, Chandigarh, India

\section{Correspondence to} Dr Lokesh Saini, drlokeshsaini@gmail.com

Accepted 10 May 2018
Check for updates

To cite: Bhattacharya $\mathrm{D}$, Sharawat IK, Saini L. BMJ Case Rep Published Online First: [please include Day Month Year]. doi:10.1136/ bcr-2018-225341

\section{DESCRIPTION}

A 12-day-old boy, first born to a non-consanguineous Indian couple, presented with a history of antenatally diagnosed hydrocephalus during ultrasound at 32 weeks. Antenatal period was uneventful, and the child was born at 37 weeks (early term) by spontaneous normal vaginal delivery with Apgar scores of 8 and 9. His weight and head circumference at birth were $2.4 \mathrm{~kg}$ and $33 \mathrm{~cm}$, respectively. There was no family history of bleeding disorders or maternal intake of anticoagulants, and the baby had received vitamin $\mathrm{K}$ injection at birth. No genetic test or amniotic fluid analysis was performed antenatally. Examination revealed a well-thriving child with no evidence of liver disease, rash, skin bleeds or encephalopathy. The anterior fontanelle was tense, with normal neurological examination.

Postnatal ultrasonography (USG) of the cranium at 6 hours of life revealed dilated ventricles with echogenic material in the occipital horn of the right ventricle, along with germinal matrix haemorrhage and intraventricular haemorrhage (IVH). MRI of the brain was done at 20 hours of life and showed dilated lateral ventricles with intraventricular and germinal matrix haemorrhage, along with obstructive hydrocephalus (figure 1). Haemogram and liver function tests were normal. Coagulation profile at 30 days of life revealed isolated prolongation of Activated Partial Thromboplastin Time (aPTT) (43.6s') (normal range: 23-35 s), which did not get corrected with vitamin K. Factor IX was reduced $(0.28 \mathrm{U} / \mathrm{mL})$ (normal: $0.43-$ $1.21 \mathrm{U} / \mathrm{mL}$ ), while factor VIII and von Willebrand factor levels were normal. The baby was followed up with serial head circumference monitoring and neurological examination until 6 months of age.

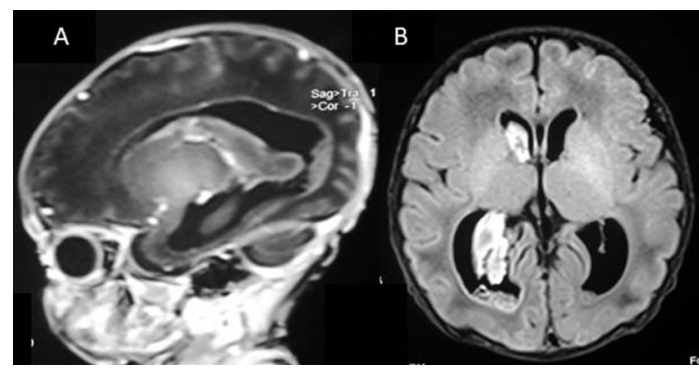

Figure 1 MRI of the brain:T1-weighted sagittal section (A) showing obstructive hydrocephalus with germinal matrix haemorrhage. Fluid-attenuated inversion recovery axial section (B) showing intraventricular haemorrhage in the right lateral ventricle with dilatation of the occipital horn.

\section{Learning points}

- Intraventricular haemorrhage (IVH) in a term newborn with uneventful perinatal course is rare and secondary causes should be ruled out.

- IVH with hydrocephalus is an extremely rare presentation of haemophilia B.

- Fetal MRI may be more sensitive in picking up antenatal intracerebral haemorrhage.

- Coagulation disorders must be considered as a differential for cause of IVH in a neonate without any risk factors.

There was no rapid increase in head size, or evidence of encephalopathy or focal neurological deficit. USG of the cranium at 4 months and 6 months of age showed complete resolution of the haemorrhage as well as hydrocephalus. Repeat coagulation testing at 6 months of age revealed prolonged aPTT (48 s') with a reduced factor IX level $(0.23 \mathrm{U} / \mathrm{mL})$.

$\mathrm{IVH}$ is a relatively common finding in premature neonates and is usually due to bleeding in the immature germinal matrix. Obstructive hydrocephalus is a well-known complication following grade III and IV haemorrhages. IVH with obstructive hydrocephalus is extremely rare in term infants and warrants extensive evaluation. Haemophilia presents in neonates as extracranial bleed, especially following traumatic delivery. Intracranial bleed is a hallmark of prematurity. Disorders of coagulation are suspected usually if there is an extracranial bleed. ${ }^{1}$ Ljung $^{2}$ reported that in $50 \%$ of cases of neonatal haemophilia, suggestive family history is absent, making diagnosis difficult. IVH in a fetus has been reported, and causes are attributed to thrombocytopaenia, maternal pre-eclampsia and trauma to the pregnant mother. ${ }^{3}$ Fetal MRI is more sensitive and specific for congenital defects than two-dimensional or three-dimensional ultrasound, and may be used in cases of hydrocephalus to look for antecedent causes. ${ }^{3}$ To conclude, haemophilia is an uncommon cause of IVH in a term child and should always be considered as a possibility.

Contributors DB: patient management, literature review and preparation of the initial draft of the manuscript. IKS: patient management, literature review and preparation of the initial draft of the manuscript. LS: clinician-in-charge, critical review of the manuscript for important intellectual content and final approval of the version to be published.

Funding The authors have not declared a specific grant for this research from any funding agency in the public, commercial or not-for-profit sectors. 


\section{Images in...}

Competing interests None declared.

Patient consent Parental/guardian consent obtained.

Provenance and peer review Not commissioned; externally peer reviewed.

C BMJ Publishing Group Ltd (unless otherwise stated in the text of the article) 2018. All rights reserved. No commercial use is permitted unless otherwise expressly granted.

\section{REFERENCES}

1 Ferreira N, Proença E, Godinho C, et al. Neonatal hemophilia: a rare presentation. Pediatr Rep 2015;7.

2 Ljung R. The optimal mode of delivery for the haemophilia carrier expecting an affected infant is vaginal delivery. Haemoph Off J World Fed Hemoph 2010;3:415-9.

3 Ghi T, Simonazzi G, Perolo A, et al. Outcome of antenatally diagnosed intracranial hemorrhage: case series and review of the literature. Ultrasound Obstet Gynecol 2003;22:121-30

Copyright 2018 BMJ Publishing Group. All rights reserved. For permission to reuse any of this content visit

http://group.bmj.com/group/rights-licensing/permissions.

BMJ Case Report Fellows may re-use this article for personal use and teaching without any further permission.

Become a Fellow of BMJ Case Reports today and you can:

- Submit as many cases as you like

Enjoy fast sympathetic peer review and rapid publication of accepted articles

Access all the published articles

Re-use any of the published material for personal use and teaching without further permission

For information on Institutional Fellowships contact consortiasales@bmjgroup.com

Visit casereports.bmj.com for more articles like this and to become a Fellow 